\title{
COMMUNITY EDUCATION IN COMMUNITY DEVELOPMENT
}

\author{
${ }^{1}$ Asep Saepudin, ${ }^{2}$ Dinno Mulyono \\ ${ }^{1}$ Universitas Pendidikan Indonesia, ${ }^{2}$ IKIP Siliwangi \\ 2dinno@ikipsiliwangi.ac.id
}

\begin{abstract}
In the framework of developing community education, education service programs, especially those related to improving community welfare, need to get special studies, especially in supporting theories implemented. It also implies new approaches, techniques and concepts that must be key words in building people's lives. Community education understands that corrections to past approaches need to be adjusted in the midst of continuous changes in the community, so that new studies are needed that are more in line with the challenges and needs of the community and new knowledge.
\end{abstract}

Keywords: community education, community development

\section{INTRODUCTION}

In the National Education System Act, it is stated, "National education functions to develop capabilities and form dignified national character and civilization in order to educate the nation's life, aiming at developing potential students to become human beings who believe and fear God Almighty, noble , healthy, knowledgeable, capable, creative, independent, and a democratic and responsible citizen, "(National Education System Law Number 20/2003). This indicates that education and development are a series that cannot be separated from one another. Therefore a more comprehensive and sustainable approach in the world of education is needed, not only by using an approach that is limited to providing certificates or diplomas, but it does not provide accessibility for education services for the Indonesian people as a whole.

The existence of education is inseparable from UNESCO's educational goals, namely learning to know, learning to do, learning to be and learning to live together. With these four pillars, it is explained that in the process education runs in accordance with human needs in their lives. Not within the framework of educational completion which leads to a diploma which often causes problems in the form of discrepancies between diplomas and fields of work that are in accordance with the talents and needs of the people themselves. According to data from the Central Statistics Agency in 2017 (Mustikoaji, 2017), the high unemployment rate at undergraduate education (606,639 people) compared to education under elementary school $(546,897$ people) critically shows that there are not too far differences between undergraduate education and their who did not even complete elementary school education. So in this, UNESCO's view of being able to build education with the full objective of learning to be and to live together is a necessity in the midst of the challenges of today's society. Education cannot only build one path of education, but all pathways of education, because the dichotomy only makes education go on each other without being able to answer the challenges of life in a global context, so that local potential is forgotten and left behind globally. 
The role of the community in education is important, not only waiting for help from the government. Society provides a big role in building and developing education. This is because in society there is intensive social interaction (Soekanto, 2004). Therefore, both in the world of Indonesian education gave birth to a concept of community education aimed at building the power of social awareness that is mutually beneficial. The concept of consciousness itself, is built in the framework of the praxis strength of social and intellectual life that supports each other. Education with a social basis is expected to provide added value in forming the character of the community itself. Not in the context of the pathway per education path that seems to narrow the space for education in the community. Because the community is the estuary of all educational processes, where education provides an opportunity for every human being to be able to move into himself by presenting the greatest benefit to the social life around him.

Equality of education is included in every educational path in Indonesia, all of which are inseparable parts. Naming the path that seems to be a separate field of study will only break the coordination of the community development system itself and disintegrate social capital that should work together with each other and work together to become a unity. Therefore, it is needed a unity of programs that complement each other with the same definite steps, because the estuary of education itself is community development, it is appropriate if we are prioritized to be able to fill a community education program that is able to provide continuity in strengthening education in Indonesia. Because education itself is not standing between educational paths, but in the midst of communities that complement each other. Building an active citizens is a necessity of the world of education (Tett, 2010).

The problem of education that has been symptomatic is the problem of relevance, quality and equitable education. The relevance of education is constrained because the output produced is not in accordance with the demands of the community, other than that, the quality of education also invites various questions, especially related to various products produced from the world of education itself that have not demonstrated their ability to respond to problems and problems in society. and, finally, education equity which leads to the availability of educational services for the entire community. Therefore, if later the development of education is released from its main estuary, namely the community, it will certainly have an impact on the ability of the graduates themselves. This in Freire (1984) is a form of alienation of education that gives birth to new problems, not an alternative to solving problems in the midst of a society that is trying to answer the various challenges that exist.

\section{THEORITICAL REVIEW}

\section{Philosophical Foundation of Community Education}

Philosophically, public education still puts forward a philosophical approach as taught by $\mathrm{Ki}$ Hadjar Dewantara, as the father of education in Indonesia as one of the main foundations of community education. This is because Ki Hadjar Dewantara's philosophy with educational nationalism teaches that how education is built on three main pillars. The pillar is ngarso sung tulodo, ing madyo mangun karso and tut wuri handayani. The first pillar that mentions sung sungodo is the meaning that each educational process requires a character, a model in the practice of education itself. On various occasions, the main problem of education in Indonesia is the poor character who can be used as the main model in the development of people's lives. Education does not merely speak of the power of theory in building development infrastructure, providing how to provide references to figures of reformers, who are productive and actively campaign for community development with the strength of social 
capital and the ecological potential they have. The second pillar is ing madyo mangun karso, in the middle giving strength. In this context education requires practitioners who master and are able to map various solutions to development problems in the community, not to add to existing problems. Educators, managers, instructors are the implementing parts that become strength builders in the community in collaboration with the community itself. So that development can be developed sustainably and in accordance with community needs. Third pillar, tut wuri handayani, who is behind giving encouragement. In particular educational development studies not only require initiators, but also require the support of leaders and stakeholders in the education of the community itself, so that various programs can run according to the targets set. Encouragement is not only in the form of material but also moral, the support of various parties in the development of education in Indonesia is a necessity and necessity in providing the right portion in the context of complete Indonesian human development.

Ki Hadjar Dewantara's philosophy, in general, is in line with the thinking of constructivists. Everyone needs to support and strengthen each other within the framework of future education development, so that they can have a positive impact on improving the lives of Indonesian people going forward. Everyone is actively involved, even though the principle of mutual respect for the potential of each other. The praxis of reality-based education in the field is also expected to provide valuable experience in order to prepare the output of educational programs to participate in the development of surrounding communities.

\section{Theory of Lifelong Education}

Lifelong education (life long learning) is a statement and conviction that in the process of the journey of human life can not be separated from the process of learning and learning. Humans will continue to learn, since in the womb until later toward the time to the grave. Humans start the learning process after the sense of hearing functions in the womb, then learn to master basic competencies related to biological abilities that must be mastered, such as walking, talking and interacting with parents. Humans then learn to be able to interact and place themselves in a wider environment in the midst of society, then study the summary of human life experiences in the form of theories that exist in the school bench. Everything requires a learning process and humans continue to need education. If then the question arises whether what is produced from the human learning process to master good walking techniques, then the answer is competence, not a diploma. Because there was never one toddler who was certified in his ability to walk after 12 months of birth. This then needs to be reviewed, that the current diploma seems to be a new deity, even many young people depend on their lives only for a piece of paper called a diploma, then forget their duty to learn to understand that real life can only be learned when he comes down and engages in social life around it, this is what is known as diploma disease.

The lifelong journey of man (lifelong) contains developments and changes that include three components, namely the stages of individual development (toddlerhood, childhood, schooling, adolescence, and adulthood), common social roles within life, which varies in each environment, and aspects of personality development (physical, mental, social, and emotional) (Mudyahardjo, 2001). Awareness of the social role that is carried out by each member of the community has their own character that must complement each other, so that no conditions are truly the same. But because of that difference, everything can complement each other. 
In the UNESCO text on Institution For Education (1979), it was explained that lifelong education was developed on the following principles of education: a. Education only ends when humans have left this mortal world. b. Lifelong education is a strong motivation for family members to plan and conduct organized and systematic learning activities. c. Learning activities are intended to obtain, renew, and / or increase knowledge, attitudes and skills that have been possessed and who are willing or unwilling, must be owned by family members in connection with continuous changes throughout life. d. Education has a variety of goals in meeting learning needs and in developing self satisfaction for every person who conducts learning activities. e. The acquisition of education is a requirement for the development of human life, both to motivate themselves and to increase its ability, so that people always carry out learning activities to meet their needs (Saepudin, 2009).

\section{Critical Pedagogy as one of the Community Education Fundaments}

Freire once mentioned that "Education ... is the practice of freedom of means by which men and women deal critically and creatively with reality and find ways to engage in the process of transformation in their own world" (Freire, 1984). In this understanding, the picture is that education is not a rigid process, it is understood only according to educational paths which are totally incompatible with the concept of lifelong education. It should be understood that the Coombs and Ahmed (1974) report mentioning three lines of education is a form of the process of implementing lifelong education to build a community. It is not then to make education in Indonesia cut into cakes which are totally formless due to being too focused on one education path and forgetting that the basic function of education is the practice of liberation so that humans move and develop into whole human beings.

Criticism delivered by Freire (1984), and Illich (2000), not without reason. They criticized school education because they fully understood that education cannot be built using rigid buildings, rigid approaches, closed theories and frozen educational channels. The criticism of schooling education is in order to build a strength and awareness that the main context of education is human life itself, and not in the concept of how to provide life through schools, paths or artificial institutions. With the existence of various institutions, the aim is to facilitate, not just to justify that failure is the end of life. Even though humans since prehistory have never needed a diploma to live, they need to realize that they are part of the universe and try to work together and cooperate with various parties in order to build themselves and the community and even the surrounding environment.

\section{Learning Theory, Knowledge and Community Development}

Learning theory in public education is carried out by Malcolm S. Knowless (1913-1997) with an andragogical approach. Previously, education was always identified with education for children or youth with pedagogical approaches. But later, knowless denied it, and developed the concept of learning for adults and said that adults also have the ability to learn, not just children. In fact, he argued that adults have readiness and support for learning experiences to make it develop far wiser in understanding the existing learning context, also able to translate theories into applications in the community. This is also supported by studies from Paulo Freire (1921-1997) which stated that learning is not merely providing knowledge with theoretical capacity and language alone, because with this approach, only building isolated communities and unable to answer the challenges of real life itself . Especially with the learning process that only emphasizes understanding and minimal efforts to equip students with the ability to analyze problems that exist in the community. The two theories of the experts developed when they were later linked to the concept of fulfillment of needs proposed 
by Abraham Maslow (1908-1970). In the development of society, learning and knowledge are not developed using mere theoretical approaches and floating in space, but by using knowledge and using it for the development of society to achieve prosperity in the sense of independence to make choices in life. This is community development in the concept of education that empowers, and humanizes, as revealed by Freire (1984: 89).

\section{DISCUSSION}

\section{Basic Concepts of Community Education}

Community education or whatever the term develops in Indonesia, starting from Outside School Education and Non-formal Education, is a series of educational activities carried out in order to prepare human consciousness to understand their potential and the surrounding environment and make the most of it for the prosperity of society. It cannot be done if then education is only an effort to achieve diplomas, certificates or certificates only, but develops people's lives in a real way. The main problem in public education is that when the implementation of an existing program, it only relies on classical approaches and only carries out examinations as limited as formal efforts to legalize someone to keep a position. Community education is far greater than that. Community education develops more sophisticated approaches, because it must prepare humans to face their own lives and encourage them to become leaders in the changes in the quality of people's lives.

\section{Community Education Objectives}

The aim of public education is to provide opportunities for the community to broaden their knowledge and skills and build their competencies to be able to promote personal development, democracy, equality and economic and employment improvement as well as equitable welfare distribution (Ministry of Education and Research, Swedish Government, 2019).

However, in some concepts, there are also several public education goals as expressed by Westonka Public Schools (2019) which state that the goals of public education are:

a. To provide lifelong education services for the entire community.

b. To promote and build communities in order to support compulsory education programs.

c. To build a strong community, which allows everyone to achieve the best results from every potential they have.

\section{Community Education Method}

The method of community education is carried out by using several approaches, according to the 2016 Train Intercultural Mediators for a Multicultural Europe) including:

a. Presentation methods with quick benefits are implemented and information is comprehensive, but it is difficult to bring students in a critical mindset and bridge relevance to other fields of knowledge, and is very dangerous for passive learners.

b. Instructional methods, with the advantage that the instructor can organize learning in providing learning guides and can produce more reflection and critical thinking patterns.

c. Methods of discovery (discovery), with the advantage of helping learners to follow the process of intellectual and mental exploration, comfort in the learning process that suits 
the interests of participants, training in praxis, transfer of learning, but has weaknesses in promoting communication and social relations, because it focuses on individual achievements.

In the practice of learning it can be carried out with presentation patterns enriched with demonstrations, discussions by capturing questions and solutions from learners, brainstorming, working in groups, case studies, role playing, as well as interviews with practitioners / technicians directly.

The techniques and approaches used in learning must ensure several important things, including:

a. The purpose of the learning program

b. Learning context

c. Selection of learning methods and characteristics of learners

d. Expertise of trainers / instructors

e. Learning climate

f. Available time

g. Existing resources

\section{Evaluation of community education}

Assessment and evaluation of the abilities displayed by the learner, aims to estimate the degree of knowledge, skills and competencies convincingly and measurably through the participation shown during the learning process. However, evaluation in public education also not only speaks of the achievements achieved by the learners, but also those achieved by the trainers. These include the appearance shown by the trainer, such as the adequacy of learning material, the effectiveness of learning techniques and so on. The techniques and instruments for collecting data for evaluation must be in line with the intended learning objectives and learning content as well as the basic characteristics and capabilities of the learners. While evaluation instruments can be developed using questionnaires, tests of success and appearance, questions directly through tests for learners, tracking records of activities, discussions and observations.

\section{Analysis of Community Education Policies}

The education policy of the community develops according to the needs of the community itself, but it is necessary to consider that the policy can be in line with the needs of the community, so that it can become a clear corridor of work. The standard used must last until it is able to produce results that are expected to not keep changing and produce nothing. Because policies that always change are not possible to achieve perfect results because they are unable to show results even though the dissemination process is still ongoing. This needs to be made into a more in-depth study for the stakeholders in the field of public education.

Community education requires a clear working corridor, but it must be considered that public education also requires a policy that is flexible and able to adapt to the needs of the 
community quickly, especially in the current industrial era 4.0. Although not entirely in the form of an industrialization process, because over time, now also raises problems where the social potential-based industrial sector is very wide open. New professions are emerging and developing very fast. This is what needs to be anticipated by community education in the future.

\section{Scope of Community Education}

To be able to understand the scope of public education going forward, we need to consider the picture below:

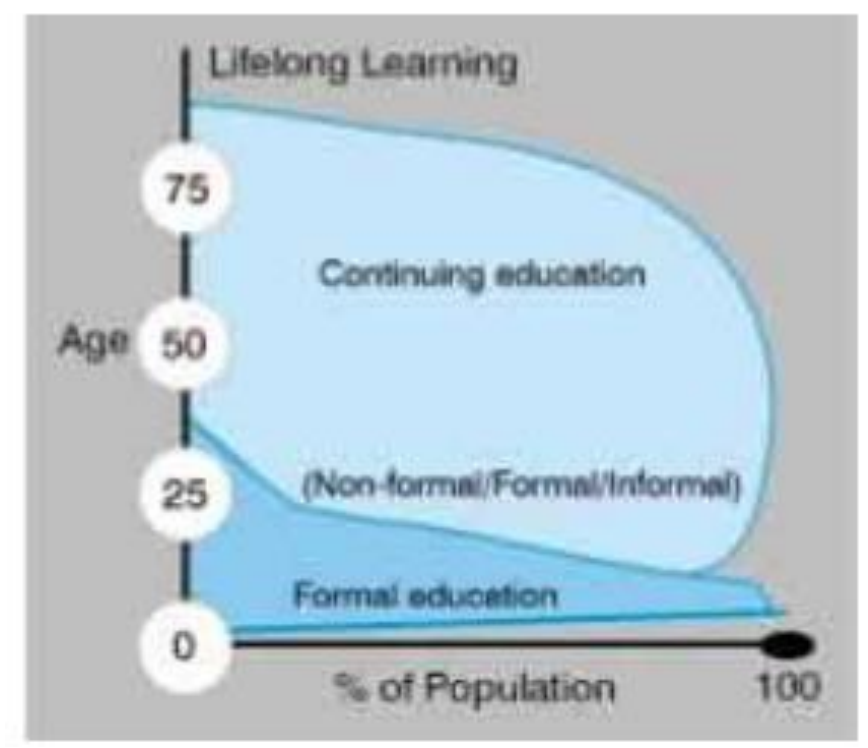

Figure 1. Differentiation of learning programs according to age and population composition (Source: http://www.accu.or.jp/litdbase/pub/p_man1/eiceg/CHAP2.pdf)

For public education, the greatest coverage arises from the concept of lifelong learning. When observed from the picture above, an understanding emerges that lifelong learning requires specifications and clarity for each program.

The scope of public education according to Kenny (2018) is:

a. In personal scope:

1) Increased self-esteem and self-esteem

2) Increased communication skills

3) Increased ability to commit and achieve specific goals

4) Increased knowledge, skills and competencies

5) Increased motivation and hope

6) Increased awareness of education and life choices

7) Ability to think analytically critically

8) Readiness in facing the accreditation process 
b. In the collective / social sphere:

1) Building a network of mutually beneficial cooperation

2) Building social analytical awareness

3) Building capacity to influence government policies and decision making

4) Ability to organize individuals and group development

5) Ability to take action on social and community issues

\section{Challenges of Community Education in the Future}

Community education in the future will be faced with a growing number of problems, including policies that must constantly change according to the needs of the community and the development of science, the challenges of educational equality, problems in the quality of community education amid the need for educational flexibility, the use of learning related to real life, changes in public education standards in accordance with the development of the demands of the industrial and business world.

\section{CONCLUSION}

Community education develops according to the demands of needs and changes in society. Various criticisms developed are not intended to assess but as a thought to build a world of education that is more developed and far better in the future. Community education does not only develop as a complement, substitute or enhancer, but rather becomes an alternative education that can be one way in order to improve the quality of public education as a whole and in accordance with the needs of the community.

\section{BIBLIOGRAPHY}

accu.or.jp. (2016, -- --). http://www.accu.or.jp. Retrieved February 04, 2019, from http://www.accu.or.jp: http://www.accu.or.jp/litdbase/pub/p_man1/eiceg/CHAP2.pdf

Europe, T. I. (2016, -- --). www.mediation-time.eu. Retrieved February 03, 2019, from www.mediation-time.eu: time.eu/images/TIME_O5_Trainer_Course_Module_2.pdf

Freire, P. (1984). Pendidikan Kaum Tertindas. Jakarta: LP3ES.

Illich, I. (2000). Bebaskan Masyarakat dari Belenggu Sekolah. Yogyakarta: Yayasan Pustaka Obor.

Kenny, M. (2018, -- --). Community Education and Development. Retrieved FEbruary 02, 2019, from Community Education and Development: http://mural.maynoothuniversity.ie/1233/1/Community_Education_\&_Development_N otes.pdf

Ministry of Education and Researh, S. G. (----, ---- ----). oktataskepzes. Retrieved February 02, 2019, from oktataskepzes: http://oktataskepzes.tka.hu/documents/7_Lifelong_learning/3_LLL_strat_hatarokon_ati velo_fej1/2_2009_2010/4_Nemzetkozi_talalk_wsok/presentation_sweden.pdf

Mudyahardjo, R. (2001). Pengantar Pendidikan. Jakarta: Rajawali Press.

Mustikoaji, H. (2017, Oktober 24). Ekonomi. Retrieved Maret 12, 2018, from Kompasiana: https://www.kompasiana.com/hendymustikoaji/59ee29cdc839c051b9465dc5/banyaksarjana-menganggur-apa-dan-siapa-yang-salah 
Saepudin, A. (2009). Implementasi Pendidikan Sepanjang Hayat pada Institusi Keluarga. Jurnal Pendidikan Luar Sekolah, Vol 4 (2), 859-869.

School, W. P. (2019, -- --). Westonka Public School. Retrieved February 02, 2019, from Westonka Public School: https://www.westonka.k12.mn.us/Page/319

Soekanto, S. (2004). Sosiologi, Suatu Pengantar. Jakarta: RajaGrafindo Persada.

Tett, L. (2010). Community education, learning and. Ediburgh, UK: Dunedin Academic Press Ltd. 